\title{
A beacon of hope: distribution and current status of the largetooth sawfish in Costa Rica
}

\author{
J. A. Valerio-Vargas ${ }^{1,3, *}$, M. Espinoza ${ }^{1,2}$ \\ ${ }^{1}$ Centro de Investigacíon en Ciencias del Mar y Limnología (CIMAR), Universidad de Costa Rica, 2060, San José, Costa Rica \\ ${ }^{2}$ Escuela de Biología, Universidad de Costa Rica, 2060, San José, Costa Rica \\ ${ }^{3}$ Sistema de Estudios de Posgrado en Biología, Universidad de Costa Rica, 2060, San José, Costa Rica
}

\begin{abstract}
The Critically Endangered largetooth sawfish Pristis pristis is one of the most threatened elasmobranch species and is currently thought to be locally extinct in at least 27 countries. Although largetooth sawfish information in Central America is scarce, recent records show that this species is still present in Costa Rica, yet its distribution and current status remain unclear. This study investigated the spatial and temporal distribution of the largetooth sawfish in Costa Rica and identified local threats affecting the populations. We conducted 275 structured interviews in coastal and riverine communities across the country, which resulted in 134 confirmed records in the Pacific, 1 in the Caribbean and 51 in the northern region. Historical and recent records suggest the largetooth sawfish has undergone significant reductions in abundance and distribution from coastal and riverine areas, mainly due to interaction with fishing gear such as gill nets and hook and line. Most sawfish captured by gill nets were reported in the Central Pacific region, whereas hook and line records were more common in the northern region and the South Pacific. Although largetooth sawfish populations in Costa Rica have followed the global decline trend, we found 2 main hotspots where recent sightings and captures appear to be more common, suggesting there is still hope for the species to recover in Costa Rica and possibly in the region. Moreover, Costa Rica recently became the $17^{\text {th }}$ country to ratify national legal protection for sawfishes, which may strengthen conservation efforts to protect populations locally and in the Central American region.
\end{abstract}

KEY WORDS: Pristis pristis $\cdot$ Maps $\cdot$ Hotspots $\cdot$ Central America $\cdot$ Legal protection $\cdot$ Interviews

\section{INTRODUCTION}

Sawfishes (Pristidae) are the most threatened group of cartilaginous fishes (Dulvy et al. 2016), with all 5 species listed as either Critically Endangered or Endangered by the International Union for the Conservation of Nature (IUCN) Red List (Harrison \& Dulvy 2014). Throughout their distribution, sawfishes have experienced significant population declines $(>95 \%)$ and reductions in geographic range of up to $81 \%$, which has resulted in extirpation and/or local extinctions (Carlson et al. 2013, Dulvy et al. 2014). The Critically Endangered largetooth sawfish Pristis pristis, once a circumtropical species, has become

*Corresponding author: jvaleriovargas@gmail.com locally extinct in 27 countries, and the lack of data from Central America has hindered management and conservation efforts to ensure its long-term survival in the region (Dulvy et al. 2014, Mendoza et al. 2017). Sightings in Nicaragua, Panama and Costa Rica over the past $10 \mathrm{yr}$ suggest that the species may still be present in Central America, but its current distribution and status remain unclear.

Coastal fisheries, including bottom trawling and gillnets, have played a major role in the decline of the largetooth sawfish throughout its distribution (Kyne et al. 2013, Harrison \& Dulvy 2014). Fishing, even at low levels of exploitation, has been identified as the main driver of the global decline and extinc-

(C) The authors 2019. Open Access under Creative Commons by Attribution Licence. Use, distribution and reproduction are unrestricted. Authors and original publication must be credited. 
tion risk of the largetooth sawfish (Kyne et al. 2013). Given their slow growth rates, late maturity (8 to $10 \mathrm{yr}$ ), and low fecundity (7.3 mean litter size), largetooth sawfish have extremely low intrinsic rates of population increase ( 0.03 to $0.07 \mathrm{yr}^{-1}$ ) (Thorson 1976, Simpfendorfer 2000, Peverell 2009). Moreover, this species is characterized by its large size $(>6.5 \mathrm{~m}$ total length), slow-moving behavior and distinctive long toothed rostrum, making it extremely vulnerable to entanglement in nets and other fishing gear.

Substantial habitat loss and degradation of critical habitats has also contributed to the decline of largetooth sawfish populations (Peverell 2009, Hossain et al. 2015). As a coastal euryhaline species, the largetooth sawfish occurs in a wide variety of coastal and riverine habitats. Adults are mainly found in marine and estuarine environments, while juveniles have greater affinity for rivers, mangroves and wetlands (Kyne et al. 2013), all of which are substantially impacted by human activities (e.g. agriculture, aquaculture, and dams) and/or rapid coastal or riverine development (CITES 2007, Peverell 2009, Hossain et al. 2015). The largetooth sawfish is also vulnerable to climate change, as predicted changes related to sea level rise and rainfall or runoff regimes could affect the structure and function of their critical coastal and estuarine habitats (i.e. mangroves, rivers and wetlands) (Chin et al. 2010, Polidoro et al. 2010, Wenger et al. 2011, Kyne et al. 2013).

The largetooth sawfish has a global tropical or subtropical distribution consisting of 4 subpopulations: Eastern Atlantic, Western Atlantic (WA), Eastern Pacific (EP) and Indo-West Pacific (Faria et al. 2013, Dulvy et al. 2016). The WA and EP subpopulations occurred in coastal and freshwater ecosystems of countries in Latin America (Cook et al. 2005, Faria et al. 2013). However, according to recent studies, populations of largetooth sawfish have been decimated from México (Bonfil et al. 2017), Peru (Mendoza et al. 2017), Colombia and Venezuela (Gómez-Rodríguez et al. 2014). In some countries of Central America, knowledge about its current distribution remains uncertain due to the lack of studies and/or recent sightings (Dulvy et al. 2014). In Central America, the WA subpopulation presents scattered reports from Panama, Nicaragua, Honduras and Belize, while in the EP, recent records are only available from Nicaragua and Panama, and the species has been declared locally extinct from Guatemala (Kyne et al. 2013).

Historically, the largetooth sawfish inhabited the Pacific and Caribbean coasts as well as the northern region of Costa Rica. However, most of the information available on the species is from research expedi- tions conducted in the 1970s and 1980s and is restricted to a few locations in the northern region (San Juan-Colorado river) and the Caribbean (Thorson 1976, 1982a,b). The species has also been reported in the North, Central and South Pacific regions (Winemiller 1983, Chicas-Batres 1995, Bussing 1998), with additional sightings in some of the main tributaries of the San Juan river (Bussing 1998), including a report from the Sarapiquí river by a Swiss settler in 1869 (Hilje \& Fournier 2017). Although some interviews in the South Pacific region from 2004 and 2011 suggest that the Corcovado National Park and TérrabaSierpe National Wetlands (TSNW) may still hold viable populations, fishers from Gulf Dulce (South Pacific region) claim they have not seen a sawfish in decades (Kyne et al. 2013).

Given recent global population declines and local extinctions of largetooth sawfish, knowledge of their distribution, abundance and threats impacting their populations, particularly in data-poor countries, remains crucial to developing effective management and conservation approaches at both local and regional scales. This study investigated the status of the Critically Endangered largetooth sawfish in Costa Rica by collecting local ecological knowledge through interview data in coastal and riverine communities. Our study addressed an important challenge previously identified in the literature, which was generating detailed data on the freshwater distribution of the largetooth sawfish (Dulvy et al. 2016, Fernandez-Carvalho et al. 2014). Moreover, we provided critical information on local threats affecting sawfish in the entire country. This information is necessary to develop effective conservation measures for the species in the Eastern Pacific (Kyne et al. 2013). Specifically, we (1) determined the current and historical distribution of the species in the entire country; (2) identified local threats affecting their survival; and (3) gathered information about the cultural importance and uses of the species to locals. These outcomes provide a more comprehensive understanding of the current status of largetooth sawfish in Costa Rica and contribute to a complete global evaluation of the species. In addition, we documented some records of the smalltooth sawfish Pristis pectinata in the Caribbean of Costa Rica.

\section{MATERIALS AND METHODS}

\subsection{Study area}

The study was conducted in coastal and riverine communities from the Pacific, Caribbean and north- 
ern region of Costa Rica. The Costa Rican Pacific coastline is $1254 \mathrm{~km}$ in length and is characterized by numerous bays, gulfs, estuaries and mangrove forests (Cortés \& Wehrtmann 2009). Mangrove cover is predominantly distributed near the mouth of large rivers, including the Tempisque (Gulf of Nicoya in the Central Pacific), and the Grande de Térraba and Sierpe (South Pacific). The lowlands of the latter 2 rivers form the TSNW, a highly productive, diverse and economically important wetland in Costa Rica (Mainardi 1996). The Caribbean coastline is smaller (212 km in length), less irregular and characterized by a small number of mangrove patches located mainly in the south (Gandoca-Manzanillo). In the central and north Caribbean, there are coastal lagoons associated with important rivers such as the Tortuguero, Matina, Pacuare and San Juan-Colorado (FAO 2004). The northern region of Costa Rica is characterized by numerous rivers and lagoon systems such as Caño Negro, one of the most important wildlife refuges in this region. All of the freshwater bodies in the region, including large rivers such as Sarapiquí, San Carlos and Frío, are major tributaries of the San Juan-Colorado river system (a natural boundary between Costa Rica and Nicaragua), which flows into the Caribbean Sea

(Barrientos \& Chaves 2008).

\subsection{Interview surveys}

Given that sawfish are rare and are often restricted to poorly accessible areas, determining their current status and distribution in most places is challenging and has limited the implementation of effective conservation strategies (Simpfendorfer et al. 2016). Interviews have been employed as a valid ecological tool for evaluating sawfish distribution, although they are dependent on the willingness of interviewees to collaborate (Poulakis \& Seitz 2004, Leeney \& Downing 2016, Simpfendorfer et al. 2016). During this study, most interviewees were willing to collaborate and expanded on the answers requested, providing valuable information on the current and historical distribution of the largetooth sawfish Pristis pristis in Costa Rica.

To determine the distribution and local threats affecting sawfishes in
Costa Rica, we conducted interviews at 42 sites across the entire country (Fig. 1). Interviews were conducted by teams of 2 people after a training period. Structured interviews aimed to target older or more experienced fishers who could have more information on historical or recent sightings, captures and local threats that may have affected the populations of largetooth sawfish. Interviews were conducted at harbors, marine supply shops, bait shops, local fish markets, restaurants, schools, fisheries cooperative buildings or at the residence of the interviewee. Although interviewees were selected as they appeared, experienced fishers were the main target. After completing the interview, interviewees were asked to provide information about other people who knew or had captured the species. Interviewers were introduced as researchers from a Sawfish Conservation initiative at the University of Costa Rica, interested in documenting the species occurrence and identifying local threats. Interviewees were shown several pictures of the largetooth sawfish and asked for permission to conduct the interview before starting. A standard questionnaire was developed, based on a survey conducted by Conservation International and the Talking Oceans Foundation in Colombia.

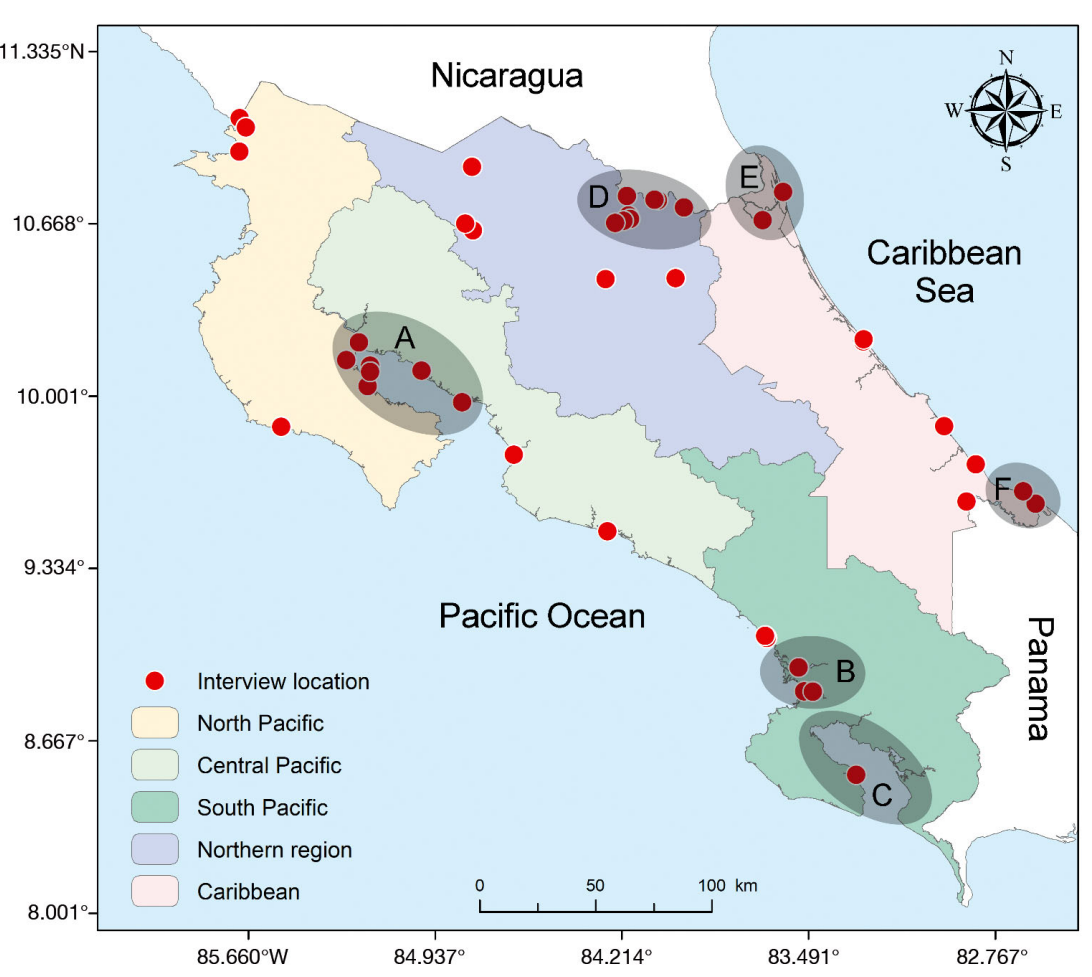

Fig. 1. Interview locations in Costa Rica, Central America. (A) Gulf of Nicoya; (B) Térraba-Sierpe National Wetlands; (C) Gulf Dulce; (D) Boca San Carlos Boca Cureña; (E) Barra del Colorado; (F) Gandoca, Manzanillo and Sixaola 
The questionnaire was adapted to include a series of questions from the Florida Program for Shark Research of the Florida Museum of Natural History. The questionnaire was applied to all interviewees.

Through the interviews, we compiled a database with historical and recent anecdotal records of sawfish sightings and/or captures for the entire country. These interviews aimed to gather detailed information on the most recent encounters by interviewees, including the date, location (approximate areas within Costa Rica), type of encounter (fished or sighted), capture method (gill net, seine, long-line, etc.), status of the animal (dead or alive), and uses (meat consumption, trophy or decoration, etc.). In addition, we documented interviewees' perceptions of the causes of sawfish decline, why sawfish were once a relatively common species in some areas of Costa Rica but now seem rare or absent, and how local threats have impacted sawfish populations.

Selection of fishing villages to conduct interviews was based on historical records and proximity to suitable sawfish habitats, such as mangroves, large rivers and other key coastal habitats such as those mentioned by Thorson (1976, 1982a,b), Winemiller (1983), Chicas-Batres (1995), and Bussing (1998). Interviews were also conducted in other locations of the country when an interviewee who had had an encounter with a sawfish did not live in a coastal or riverine community. We conducted a total of 275 structured interviews from March 2016 to October 2017, covering a large number of coastal and riverine communities from Costa Rica (Table 1). Interviewees were categorized in the following age groups: <30, 30-45, 46-60 and $>60 \mathrm{yr}$. Most interviewees $(\mathrm{n}=88)$ were in the category $>60$ yr old, while 33 were $<30$ yr old. Out of 275 interviewees, 50 did not practice any type of fishing; 18 were sport fishers, 98 were commercial fishers (trawl, gill net, or longline) and 109 were subsistence or artisanal fishers (hook and line). From the 275 interviews, 259 interviewees knew the species in several ways: 15 had only seen it on TV; 36 knew it from stories, pictures or had seen dried rostra as decoration. In total, 208 (80\%) of these 259 interviewees had had at least one encounter with a sawfish.

\subsection{Species identification}

Although our questionnaire aimed to gather general information on sawfishes, we were able to classify most records at the species level based on the species distribution and/or photographic records. Records from the Pacific were all assigned to the large-
Table 1. Total number of interviews $(n=275)$ by region in Costa Rica, Central America

\begin{tabular}{|lc|}
\hline Regions & No. of interviews \\
\hline Pacific & \\
Northern Pacific & 24 \\
Nicoya Peninsula & 7 \\
Gulf of Nicoya & 94 \\
Central Pacific & 2 \\
Southern Pacific & 53 \\
Northern region & 75 \\
Central Valley & 4 \\
Caribbean & \\
Northern Caribbean & 3 \\
Central Caribbean & 3 \\
Southern Caribbean & 10 \\
Total & 275 \\
\hline
\end{tabular}

tooth sawfish $P$. pristis ( $P$. pectinata's distribution is restricted to the Atlantic; Faria et al. 2013). As for the Atlantic (i.e. Caribbean coast), each record was assigned to either Pristis sp., P. pristis or P. pectinata depending on the quality of the evidence provided by each interviewee and any other additional evidence available.

\subsection{Data analysis}

To examine the spatial distribution of historical and recent sawfish sightings or captures in Costa Rica, we used the most accurate location of the last encounter of each interviewee from the database. Spatial information was categorized by region (North Pacific, Gulf of Nicoya, Central Pacific, South Pacific, Northern Region, and Caribbean), and habitat type (river, brackish or estuarine, lagoon, inshore and offshore). Sawfish records were also classified in the following time periods: $>20,11-20,5-10$, and $<5$ yr ago, using January 2018 as a reference date. Spatial data was plotted and the distribution mapped based on the time periods using ArcMAP 10.2 ${ }^{\circledR}$ (ESRI 2014). These maps provided important information on (1) historical and recent changes in the distribution and abundance of largetooth sawfish in the entire country and (2) potential hotspots or critical habitats that may be important for the conservation of this species in Costa Rica.

In addition to reports from local interviews, we included 20 records from people who provided recent pictures or information that could validate sawfish records. Given that these records were not gathered through interviews, they were only used to map sawfish distribution and were not included in the inter- 
pretations of population trends as they could bias the analysis. Of the total records, 7 of the encounters took place in Nicaragua, and the remaining 222 records were within Costa Rican waters.

To assess if sawfishes were more frequently sighted or fished, and which fishing gear was responsible for catching them, information was summarized by type of encounter and fishing gear. Information on the use of sawfish products (meat, rostra and rostral teeth), people's perception towards changes in sawfish abundance through time and local threats driving sawfish decline or disappearance from Costa Rican waters were also analyzed.

\section{RESULTS}

There were 206 confirmed records of the largetooth sawfish Pristis pristis across the entire country and only 2 records of the smalltooth sawfish $P$. pectinata in brackish waters from the Caribbean. Fourteen additional records could not be classified to species level. Given that most confirmed records (93\%) corresponded to the largetooth sawfish, major findings presented in the following sections are based exclusively on this species, hereafter referred to as sawfish.

Interview data revealed that sawfish have experienced a substantial decline through time (Fig. 2A). The number of sightings or captures declined from 89 historical records ( $>20 \mathrm{yr}$ ) to 24 in the past $5 \mathrm{yr} 8$ interviewees did not specify a time period. Species'
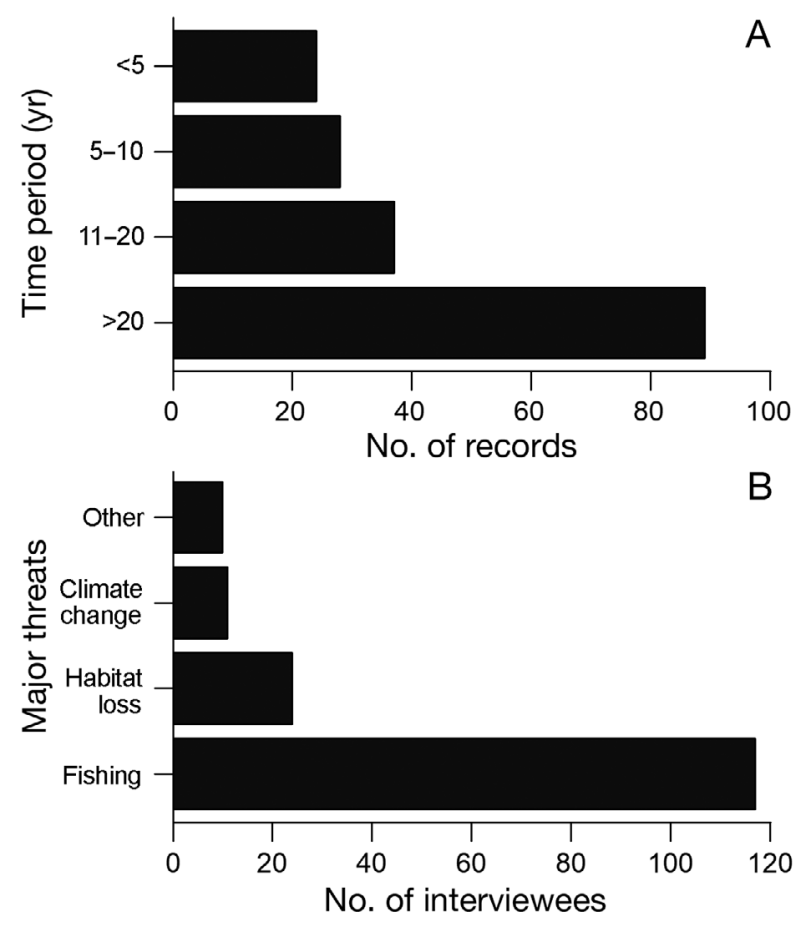

Fig. 2. (A) Interview records $(n=178)$ for number of sightings of largetooth sawfish Pristis pristis through time in Costa Rica, Central America. Eight interviewees did not specify a time period for their encounter and are not included. (B) Sawfish threats mentioned by interviews; only answers from persons who had had an encounter in Costa Rican waters were included

records decreased by $92 \%$ (Central Pacific), $80 \%$ (North Pacific), $54.5 \%$ (northern region) and 25\% (South Pacific) (Table 2). Even though sawfish re-

Table 2. Interview records $(n=178)$ for number of past sightings of largetooth sawfish Pristis pristis and additional reports $(n=20)$ in major regions of Costa Rica (Central America) by time periods, taking January 2018 as the reference date. Eight interviewees did not specify a time period for their encounter, so they are not included in this table. TSNW: Térraba-Sierpe National Wetlands

\begin{tabular}{|c|c|c|c|c|c|c|c|c|}
\hline \multirow{3}{*}{ Region } & \multirow{2}{*}{\multicolumn{2}{|c|}{$\longrightarrow>20$ yr ago $\longrightarrow$}} & \multicolumn{4}{|c|}{ Time periods -} & \multirow{2}{*}{\multicolumn{2}{|c|}{$<5$ yr ago -}} \\
\hline & & & $-11-20$ & yr ago & $-5-10$ & yr ago - & & \\
\hline & Interviews & $\begin{array}{l}\text { Additional } \\
\text { reports }\end{array}$ & Interviews & $\begin{array}{l}\text { Additional } \\
\text { reports }\end{array}$ & Interviews & $\begin{array}{l}\text { Additional } \\
\text { reports }\end{array}$ & Interviews & $\begin{array}{l}\text { Additional } \\
\text { reports }\end{array}$ \\
\hline North Pacific & 5 & & 4 & & 2 & & 1 & \\
\hline \multicolumn{9}{|l|}{ Central Pacific } \\
\hline Nicoya Península & 2 & & & & 2 & & & \\
\hline Gulf of Nicoya & 41 & & 10 & & 6 & & 3 & 1 \\
\hline Central Pacific & 7 & 2 & 1 & & 1 & & 1 & 1 \\
\hline \multicolumn{9}{|l|}{ South Pacific } \\
\hline TSNW & 9 & & 8 & & 4 & 1 & 5 & 6 \\
\hline South Pacific & 1 & & 2 & & 3 & & 3 & \\
\hline Dulce Gulf & 2 & & 2 & & & & 1 & \\
\hline Northern region & 22 & 1 & 9 & & 10 & & 10 & 7 \\
\hline Caribbean & 0 & & 1 & & 0 & & 0 & 1 \\
\hline Total & 89 & 3 & 37 & 0 & 28 & 1 & 24 & 16 \\
\hline
\end{tabular}


cords from the South Pacific and northern region have decreased historically, records in both regions remained stable when comparing the 11-20 yr and $<5$ yr categories. Additionally, sawfish records from the northern region remained stable in the 3 most recent time categories (Table 2, Fig. 3).

Sawfish records varied by region, with most sightings or captures recorded in the Central Pacific (41\%), northern region $(29 \%)$ and South Pacific $(23 \%)$ regions. Locally, most records occurred in the Gulf of Nicoya (32\%), San Juan River (21\%) and TSNW
$(16 \%)$. Sawfish were sighted or captured more frequently in rivers $(35 \%)$, brackish waters $(34 \%)$ and inshore habitats $(17 \%)$, while there were fewer records from offshore sites $(7 \%)$ and lagoons $(3 \%)$. Eight interviewees did not specify the habitat at the time of the encounter.

Based on our interviews and additional data, hook and line $(32 \%)$ and gill net $(31 \%)$ were responsible for capturing most sawfishes (Table 3). The remaining sawfish encounters were mainly sighted or harpooned, the latter was found to be a common practice

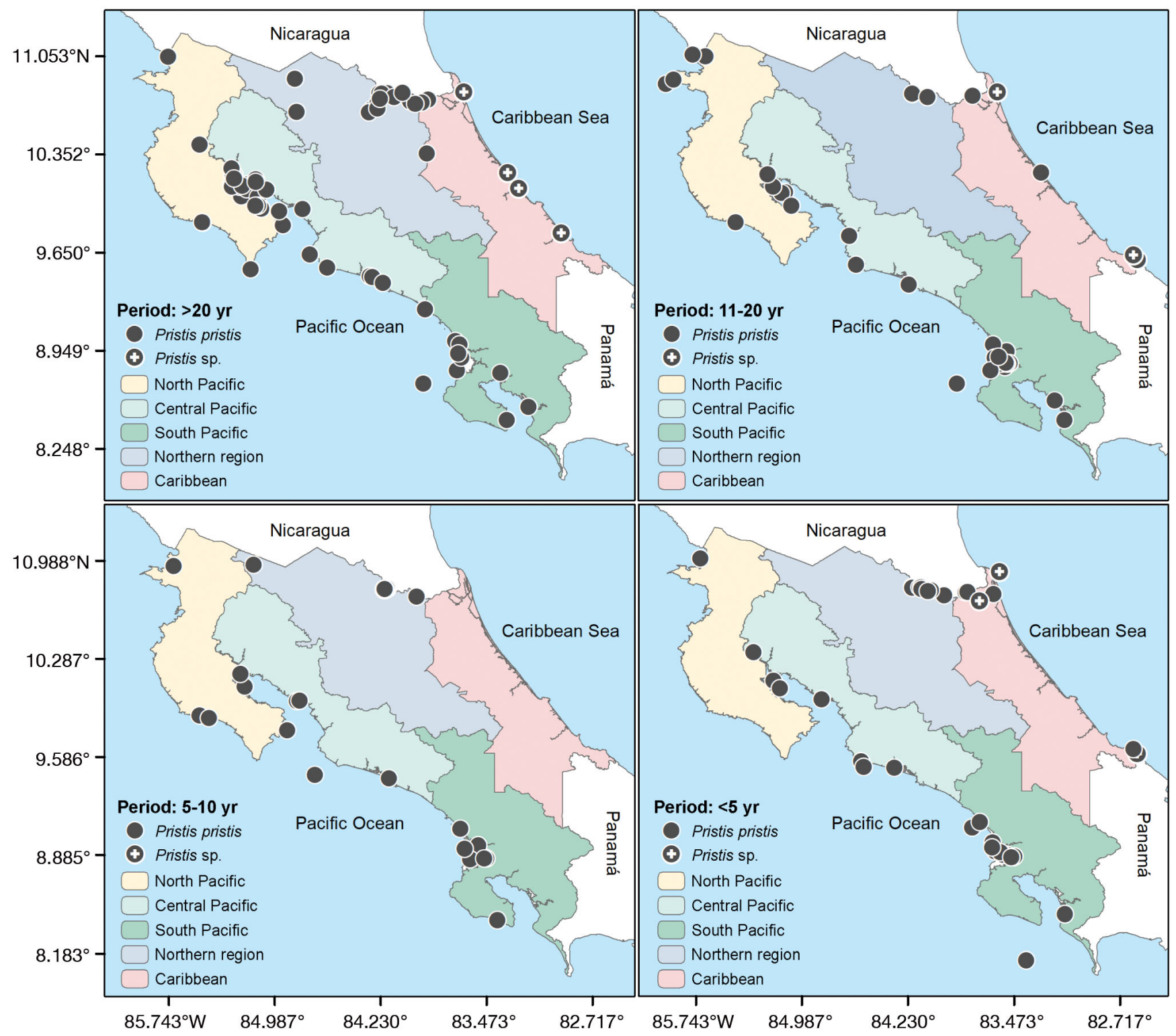

Fig. 3. Estimated historical and current distribution of the largetooth sawfish Pristis pristis (๑) in Costa Rica (Central America) from interview data $(n=186)$ and additional records $(n=20)$, taking January 2018 as the reference date. Eight interviewees did not give information on time period; therefore, those records were not included in the analysis. Fourteen sawfish Pristis sp. records $(\boldsymbol{\Theta})$ in which the species could not be identified are included 
Table 3. Total largetooth sawfish records in major regions of Costa Rica where fishing gear and type of habitat was confirmed $(n=185)$. Only records that have associated data on fishing gear, habitat, or both are included in this table. 'Other' includes a variety of situations in which sawfish were reported: poisoned by an unknown chemical; poisoned or suffocated after a massive molasses spill; entangled in barbed wire, roots and tree branches; and found dead at the beach

\begin{tabular}{|c|c|c|c|c|c|c|c|}
\hline \multirow{2}{*}{ Fishing gear } & \multirow{2}{*}{$\begin{array}{l}\text { Habitat } \\
\text { type }\end{array}$} & \multicolumn{5}{|c|}{ - Regions of Costa Rica } & \multirow[t]{2}{*}{ Total } \\
\hline & & $\begin{array}{l}\text { North } \\
\text { Pacific }\end{array}$ & $\begin{array}{c}\text { Central } \\
\text { Pacific }\end{array}$ & $\begin{array}{l}\text { South } \\
\text { Pacific }\end{array}$ & $\begin{array}{l}\text { Northern } \\
\text { region }\end{array}$ & $\begin{array}{l}\text { Carib- } \\
\text { bean }\end{array}$ & \\
\hline \multirow[t]{5}{*}{ Hook and line } & Brackish & & 10 & 8 & & & 18 \\
\hline & Inshore & & 1 & 4 & & 1 & 6 \\
\hline & Lagoon & & & 2 & & & 2 \\
\hline & Offshore & & 2 & 1 & & & 3 \\
\hline & River & 1 & 1 & 9 & 26 & 1 & 38 \\
\hline \multirow[t]{5}{*}{ Gill net } & Brackish & & 35 & 5 & & & 40 \\
\hline & Inshore & 7 & 8 & 2 & & & 17 \\
\hline & Lagoon & & & & 1 & & 1 \\
\hline & Offshore & 1 & 1 & 1 & & & 3 \\
\hline & River & & 1 & 1 & & & 2 \\
\hline \multirow[t]{5}{*}{ Sighted } & Brackish & & & 2 & & & 2 \\
\hline & Inshore & 1 & 1 & 1 & & & 3 \\
\hline & Lagoon & & & & 2 & & 2 \\
\hline & Offshore & 1 & & 2 & & & 3 \\
\hline & River & & & 1 & 6 & & 7 \\
\hline \multirow[t]{2}{*}{ Harpoon } & Brackish & & 1 & & & & 1 \\
\hline & River & & & & 14 & & 14 \\
\hline \multirow[t]{2}{*}{ Longline } & Brackish & & 1 & 1 & & & 2 \\
\hline & Offshore & & 2 & 2 & & & 4 \\
\hline \multirow[t]{3}{*}{ Trawl } & Brackish & & 1 & & & & 1 \\
\hline & Inshore & & 2 & 2 & & & 4 \\
\hline & Offshore & & 1 & 1 & & & 2 \\
\hline \multirow[t]{2}{*}{ Other } & Inshore & & 1 & & & & 1 \\
\hline & River & & & & 9 & & 9 \\
\hline Total & & 11 & 69 & 45 & 58 & 2 & 185 \\
\hline
\end{tabular}

fish. A total of 12 interviewees reported cutting the saw at the time of the encounter; 2 of these interviewees were retired shrimp trawl captains who discarded the sawless sawfish while it was still alive.

In terms of sawfish uses, 200 interviewees said that sawfish rostra were kept and used as trophies. Fishers from the Gulf of Nicoya mentioned that they historically (>20 yr) used to keep rostra for national customers who had previously ordered them. However, our interview results indicate that this was also a recent practice in the northern region, as several interviewees reported a Panamanian buyer regularly visited the area in search of rostra to use as decoration in a hotel in his home country. Traditional medicinal uses of sawfish rostra were only mentioned by 7 interviewees. Medicinal properties, such as curing headaches and prevention of baldness, did not involve the consumption of the rostrum; instead, the rostrum was used to comb one's hair to cure the illness. Another medicinal property was the extraction of calcium to make a supplement in the northern region in recent years. Ten other sawfish were poisoned by an unknown chemical in the San Juan River (northern region); poisoned or suffocated after a massive molasses spill in the San Carlos River (northern region); entangled in barbwire, roots and tree branches; or found dead at the beach. Nineteen persons did not give information about fishing gear. Most sawfish captured in the northern region and South Pacific regions were by hook and line, whereas in the Central Pacific region, most sawfish were caught in inshore and brackish waters with gill nets (Table 3).

Of the 206 records, most sawfish (66\%) were reported dead at the time or as a result of the encounter, whereas $24 \%$ were reported alive or the person did not give any information about the fate of the animal. Interview data regarding deceased sawfish indicate they were sold in local markets or used for consumption; 6 interviewees discarded the saw- used for bone strengthening, but the process was not known by the interviewee. Additional uses for the rostral teeth were also reported, including making arts and crafts, fabrication of cock-fighting spurs, and to prepare invigorating beverages for pregnant women by grinding the sawfish teeth to a fine powder.

A large proportion ( $72 \%$ ) of interviewees who had had an encounter with a sawfish mentioned that overfishing was the major threat responsible for sawfish decline. Other threats such as habitat loss or degradation (15\%) and climate-related changes (7\%) were also considered important. Ten interviewees mentioned that other causes such as emigration $(n=3)$, low reproductive success $(n=2)$, limited food sources $(n=2)$, low natural abundance $(n=1)$, predation by crocodiles $(n=1)$, and introduced species (e.g. loricariid fishes in the San Juan river watershed) were also impacting sawfish populations in Costa Rica (Fig. 2B). 


\section{DISCUSSION}

Based on our findings, the distribution and abundance of the largetooth sawfish Pristis pristis in Costa Rica has experienced a significant reduction, mainly due to fishing pressure in both coastal and riverine habitats. Nonetheless, we documented at least 2 hotspots in which recent sawfish sightings or captures were more common than in other areas: the TSNW in the South Pacific and the San Juan river watershed in the northern region. Sawfish had a broader distribution in the country than previously understood, including a wide range of freshwater, brackish, inshore and offshore habitats not previously reported as sawfish occurrence areas by Thorson (1976, 1982a,b), Winemiller (1983), ChicasBatres (1995), Bussing (1998) and Hilje \& Fournier (2017). These results highlight that some areas of Costa Rica may need special attention and that additional conservation efforts on key estuarine and freshwater habitats are needed in order to assist in recovery of populations of this critically endangered species.

Changes in the number of historical ( $>20 \mathrm{yr}$ ) and recent ( $<5 \mathrm{yr}$ ) records of largetooth sawfish in Costa Rica suggest there have been significant declines in both the Eastern Pacific and Western Atlantic subpopulations. The decline of largetooth sawfish in Costa Rica is consistent with global decline trends (Dulvy et al. 2014, 2016, Harrison \& Dulvy 2014). Moreover, similar regional patterns have been described, as population reductions of largetooth sawfish have been reported in Mexico (Bonfil et al. 2017), Nicaragua (Thorson 1982b), Colombia (Caldas et al. 2017), and Venezuela (Gómez-Rodríguez et al. 2014). The largetooth sawfish was declared locally extinct in Guatemala, Peru and Ecuador; however, recent records suggest there may be a population remnant in the latter 2 countries (Mendoza et al. 2017).

Our study showed that most historical records ( $>20 \mathrm{yr}$ ago) were from the Gulf of Nicoya in the Central Pacific, one of the largest and most important estuaries of Costa Rica (Lizano \& Vargas 1993, Vargas 1995). This estuary has been subject to intensive marine resource extraction (Lizano \& Vargas 1993, Zanella et al. 2009) and is considered to have been overfished since the 1990s (Chacón et al. 2007, Tabash-Blanco 2007), which coincides with the time frame of most captures in this estuary. In this period ('>20 $\left.\mathrm{yr}^{\prime}\right)$, most sawfish captured in the Gulf of Nicoya were entangled in gill nets, which are still the most widely used fishing gear in the estuary (Chacón et al. 2007). According to fishers, some sawfish captured in this gulf during the rainy season were pregnant females, and, in some instances, they aborted their fetuses when captured. This suggests that the Gulf of Nicoya and possibly the Tempisque River were likely a sawfish pupping ground.

Recent largetooth sawfish sightings are concentrated in 2 main regions. One of these is the northern region, specifically the San Juan watershed which represents a natural boundary between Nicaragua and Costa Rica. Together with Lake Nicaragua and the Colorado River, the San Juan watershed was considered to have one of the greatest freshwater concentration of sawfish in the world during the 1960s (Thorson 1982b). However, in the 1970 s, an intense commercial netting fishery operating in Lake Nicaragua was responsible for a rapid decline of the largetooth sawfish population (Thorson 1982b). After the population was decimated, Nicaragua placed a 2 yr moratorium on the capture of sawfish in 1981 and an indefinite no-take status since 2002 (Thorson 1982b, McDavitt 2002, Ministerio del Ambiente y los Recursos Naturales 2002). Recent sawfish sightings along the border with Nicaragua may suggest a potential recovery of the population due to the no-take status in Nicaragua for $>15$ yr. Conversely, local enforcement of fishing regulations is still a major problem in this region as exemplified by the use of illegal fishing gears, such as harpoon and gillnets. Harpoon fishers in the San Juan River watershed target Atlantic tarpon Megalops atlanticus for commercial use, but due to limited visibility conditions, they likely kill sawfish incidentally; for example, nearly all recent sawfish records from this region were from harpoon fishers (Fig. 4). Furthermore, hook and line fishers reported 3 sawfish in 2018 from the San Juan River and 1 gillnet capture in April 2019 from a small Costa Rican tributary of the San Juan. These encounters highlight the need to conduct further research in this region.

In addition to the San Juan River, recent largetooth sawfish records were documented in the TSNW region. This region holds one of the largest mangrove forests in Central America, comprising 17737 ha of protected mangrove area or $43 \%$ of all mangroves in Costa Rica (Mainardi 1996). While the TSNW does not hold a no-take status, it does offer protection to its mangrove forest and to certain sections of both major rivers, as regulations only allow small-scale subsistence agriculture and prohibit large-scale touristic or commercial developments (Ministerio del Ambiente y la Energía 


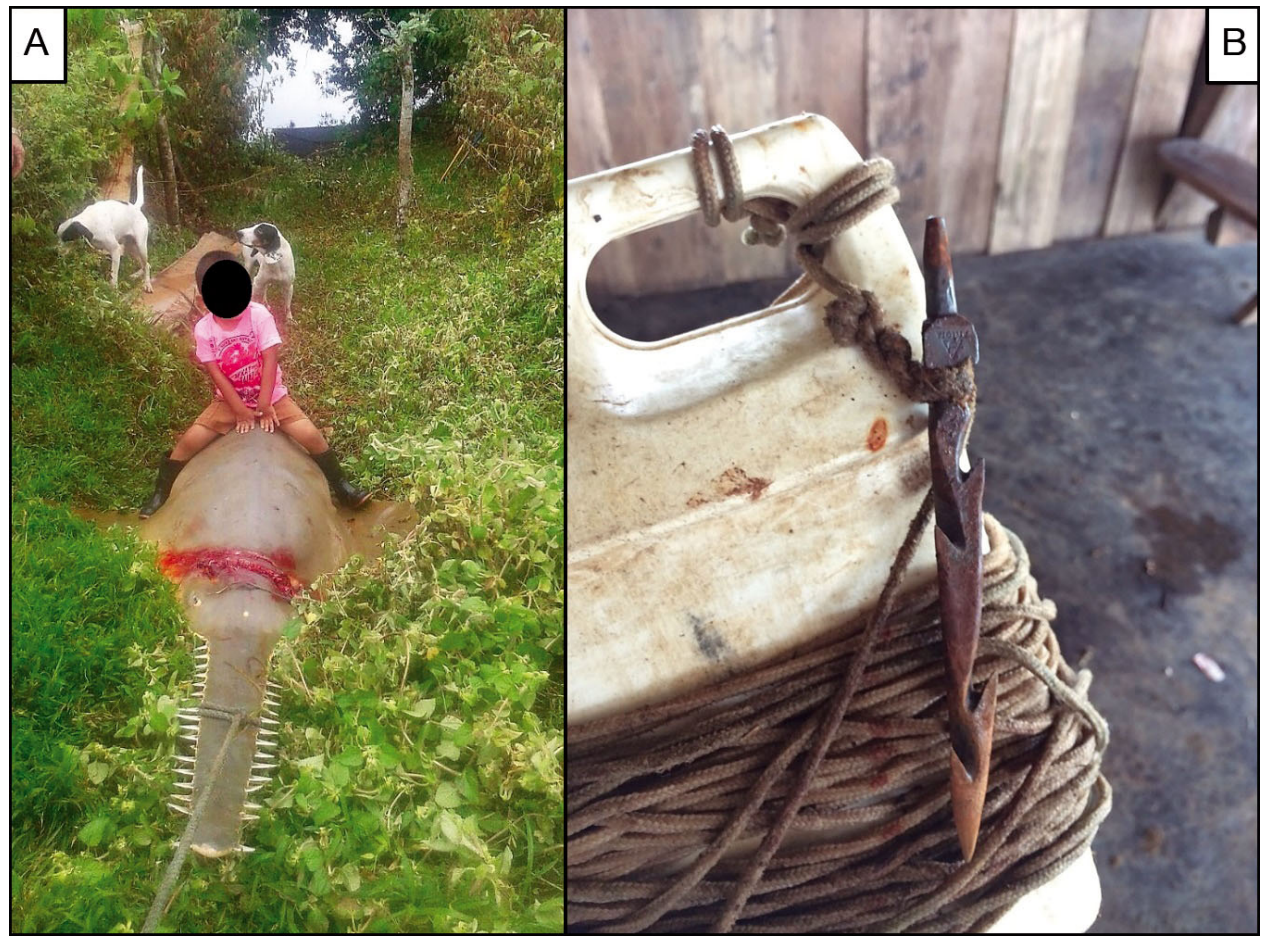

Fig. 4. (A) Largetooth sawfish killed by harpoon fishers in Boca Cureña in 2017, northern region of Costa Rica (unknown photographer). (B) Harpoon tip made out of a 3-sided file (picture by J. A. Valerio-Vargas). The file has been sharpened and grooves cut into it to hold to the flesh of tarpon or sawfish. This tip is fixed at the end of a long wood stick; once the harpoon is in the body of the animal, the tip detaches from the stick, and the animal can be traced by the floating plastic bottle acting as a buoy

2013). Collectively, these regulations have preserved sawfish habitats within the TSNW, by reducing threats such as pollution and synergistic effects from changes in land use due to deforestation for cattle grazing and extensive crops (e.g. pineapple and bananas). The vast extension of preserved sawfish habitats in the TSNW serves to explain the continuous sawfish records in this particular area. However, recently discovered illegal clearing of a marsh surrounding the Sierpe Lagoon, apparently for rice plantations in the upper reaches of the Sierpe River, uncontrolled fishing activities in surrounding inshore areas (J. A. Valerio-Vargas pers. obs.), and the loss of mangrove forest due to coastal sedimentation (Silva-Benavides et al. 2015) are threats that need to be addressed.

Sawfish meat has been reported to be sold in markets around the world (McDavitt 2002, 2014, Hossain et al. 2015, Leeney 2017). Based on our findings, sawfish meat was historically found (>20 yr) in some markets, sold primarily by gill net fishers. According to fishers from the Gulf of Nicoya, it was marketed under names such as 'posta', which could be translated to fish meat; 'posta blanca' (white fish meat); and 'tiburón' (shark). One retired fisher from the North Pacific of Costa Rica, mentioned that in the 1970s, a truck, mainly loaded with sawfish but also with shark meat, travelled weekly from Lake Nicaragua to fish markets in the capital of Costa Rica.
Thorson (1982b) mentioned that sawfish meat was exported to several countries in Central America, although the countries were not mentioned.

Sawfish parts used in traditional medicine (e.g. respiratory ailments, vision problems, rheumatism, or general pain) were described from 9 countries by McDavitt (2014). Our findings on the use of sawfish parts in Costa Rican traditional medicine differ largely from those records. One of the main differences is that the most commonly mentioned medicinal use requires the physical action of the saw to obtain cure or relief from headaches and baldness, rather than the ingestion of a sub-product of the rostrum to obtain the supposed benefits.

The use of sawfish rostral teeth to fabricate cockfighting spurs has been mainly reported from South American countries (Kyne et al. 2013, McDavitt 2014, Ogden 2015); however, the present study provides the first evidence of this activity in Costa Rica. Although countries like Brazil, Ecuador, Panama, and several Caribbean nations are the main sources of sawfish rostral teeth, Costa Rica is possibly another major source of these valued items which find their way into the international cockfighting market. More recently, one of our team members was contacted by a dealer in Ecuador requesting sawfish rostral teeth for the cockfighting industry, which provided further evidence that illegal international trade may be common in the Latin American region. 
The illegal sawfish parts trade in Costa Rica, namely rostra and rostral teeth, represents a serious threat to the remnant sawfish populations, as the international market still creates a demand that may exert greater targeted fishing pressure to the already affected populations. Evidence of this illegal trade in Costa Rica demonstrates the need to monitor this type of activity, educate and create awareness among local authorities, and enforce international regulations such as CITES and CMS agreements. Local and regional efforts are urgently needed to address illegal sawfish trade.

Ongoing research efforts to define critical habitats for sawfish in Costa Rica, and the evidence that their populations have experienced significant declines in their distribution and abundance over the past $20 \mathrm{yr}$ helped secure their legal protection by national authorities. The decree AJDIP/366-2017 (INCOPESCA 2017) protects both smalltooth P. pectinata and largetooth sawfish in Costa Rican waters in several ways: (1) a permanent fishing ban for both species, except for research purposes; (2) if a sawfish is caught incidentally, it must be reported to the authorities; and (3) sanctions will be applied if regulations are not followed. In November 2017, Costa Rica became one of 17 nations in which sawfish species have some level of legal protection. These measures respond to the urgently needed conservation efforts in its Eastern Pacific distribution (Kyne et al. 2013).

Knowledge about largetooth sawfish occurrence in riverine habitats and how local threats may affect the species' populations remains a top priority for a more comprehensive understanding of the global distribution of this species (Fernandez-Carvalho et al. 2014, Dulvy et al. 2016). According to Dulvy et al. (2016), $75 \%$ of the global historical largetooth sawfish distribution range is now regarded as presence uncertain (PU), which means the species was formerly known or thought to occur in the area, but it is no longer known if the species still occurs. At a regional scale, part of the Central American countries were considered as PU (Dulvy et al. 2016); however, recent records from this study confirm the presence of the largetooth sawfish in Costa Rica, which is now part of the extant distribution of both the Eastern Pacific and Western Atlantic populations (Faria et al. 2013). Similarly, studies from 2017 and 2018 in data-poor regions (Mendoza et al. 2017, White et al. 2017, Leeney et al. 2018) have demonstrated the persistence of the species where it was thought to be extinct or PU. This shows that there are other beacons of hope outside of Australian pro- tected areas where sawfish are found more frequently than any other country in their historical range. Nevertheless, even though there are some countries in the region where extinction has prevailed (Gómez-Rodríguez et al. 2014), we may still be in time to protect the species.

The finding of recent records and recognition of sawfish hotspots together with the achievement of legal protection measures for this Critically Endangered species gives hope for its conservation and serves to strengthen conservation actions in Costa Rica. Moreover, these outcomes will aid in international negotiations with Nicaragua and serve to increase enforcement cooperation now that both nations protect sawfish species. Back in the 1980s, Thorson (1982a) confirmed downstream and coastal movements of sawfish in the Lake Nicaragua - San Juan River system and Barra del Colorado surrounding areas in Costa Rica. This demonstrates that commercial netters at the river mouth could have an important effect on sawfish in the region; thus, sawfish conservation depends on actions from both nations. Finally, more than $30 \mathrm{yr}$ after Thorson's observation, both countries support the protection of sawfish, which could provide the means for a slow and long-term population recovery plan to save sawfish.

Acknowledgements. This research would not have been possible without the financial support from The Rufford Foundation (RSG 19361-1), PADI Foundation, The National Geographic Society (Grant \#NGS-54004C-18), IdeaWild and Costa Rica Wildlife Foundation. We also acknowledge the early support from Conservation International-Costa Rica and the conservation efforts made by Misión Tiburón in the Humedal Nacional Térraba-Sierpe. Additional support from Federación Costaricense de Pesca (FECOP), Stone Mountain Outdoors (Mark Evans), OutdoorsTV (Johnny González) and ConnectOcean (Ernst Van der Poll) facilitated our fieldwork and outreach activities. Special thanks to Jorge Salmerón, Fabiola Chirino, Laura García, Tatiana Araya, Isaac Chávez, Yahaira Barrantes, Marta Cambra, Andrea Arriaga, José Miguel Marrero and many other students who have helped us in this project. We also want to give a special recognition to Esteban Jimenez and Rubén Gonzalez for their assistance and unconditional dedication to help promote the conservation of sawfish in Sierpe and Boca San Carlos. In addition, we thank all interviewees and other people who collaborated with this investigation; this work would not have been possible without them. Finally, we thank Madalyn Cooper and 3 anonymous reviewers for their comments and revision which improved the quality of this paper. This project was funded by Vicerrectoría de Investigación (B-7172) and Vicerrectoria de Acción Social (ED-3295) from the University of Costa Rica. This research was conducted under research permits from the Costa Rican National Conservation System (SINAC ACOPAC-INV-21-17). 


\section{LITERATURE CITED}

Barrientos O, Chaves G (2008) Región Huetar Norte: oferta exportada actual y oferta potencial de productos agropecuarios alternativos. SEPSA \& PROCOMER, San José

Bonfil R, Mendoza-Vargas OU, Ricaño-Soriano M, PalaciosBarreto PY, Bolaño-Martínez N (2017) Former widespread abundance and recent downfall of sawfishes in Mexico as evidenced by historical photographic and trophy records. Fisheries (Bethesda, MD) 42:256-259

Bussing WA (1998) Peces de las aguas continentales de Costa Rica / Freshwater fishes of Costa Rica. Editorial Universidad de Costa Rica, San José

Caldas JP, Mejía-Falla PA, Navia AF, Acero PA (2017) Pristis pristis (Linnaeus, 1758). In: Chasqui L, Polanco A, Acero A, Mejía-Falla P, Navia A, Zapata L, Caldas JP (eds) Libro rojo de peces marinos de Colombia. Instituto de Investigaciones Marinas y Costeras INVEMAR, Santa Marta, p 552

Carlson J, Wiley T, Smith K (2013) Pristis pectinata, smalltooth sawfish. The IUCN Red List of Threatened Species 2013: e.T18175A141791261. http://dx.doi.org/10.2305/IUCN.UK. 2013-1.RLTS.T18175A141791261.en (accessed 3 April 2018)

Chacón A, Araya H, Vásquez AR, Brenes R and others (2007) Estadísticas pesqueras del Golfo de Nicoya, Costa Rica 1994-2005. UNA-JICA-INCOPESCA, Costa Rica

Chicas-Batres F (1995) Distribución, diversidad y dinámica poblacional de la ictiofauna comercial de la reserva forestal Térraba-Sierpe, Puntarenas, Costa Rica. MS thesis, University of Costa Rica, San José

Chin A, Kyne PM, Walker TI, McAuley RB (2010) An integrated risk assessment for climate change: analysing the vulnerability of sharks and rays on Australia's Great Barrier Reef. Glob Change Biol 16:1936-1953

CITES (2007) Proposal 17 Inclusion of all species of the family Pristidae in Appendix I of CITES. In: Fourteenth meeting of the Conference of the Parties, The Hague (Netherlands), 3-15 June. CITES, p 21

Cook SF, Compagno LJV, Oetinger MI (2005) Largetooth sawfish Pristis perotteti. In: Fowler SL, Cavanagh RD, Camhi M, Burgess GH and others (eds) Sharks, rays and chimaeras: the status of the chondrichthyan fishes. Status survey. IUCN SSC Shark Specialist Group, Gland, p 325-327.

Cortés J, Wehrtmann IS (2009) Diversity of marine habitats of the Caribbean and Pacific of Costa Rica. In: Wehrtmann IS, Cortés J (eds) Marine biodiversity of Costa Rica, Central America. Monogr. Biol. 86, Springer, Berlin, p 3

Dulvy NK, Fowler SL, Musick JA, Cavanagh RD and others (2014) Extinction risk and conservation of the world's sharks and rays. eLife 3:e00590

* Dulvy NK, Davidson LNK, Kyne PM, Simpfendorfer CA, Harrison LR, Carlson JK, Fordham SV (2016) Ghosts of the coast: global extinction risk and conservation of sawfishes. Aquat Conserv 26:134-153

ESRI (2014) ArcMap 10.2. ESRI, Redlands, CA

FAO (2004) Perfiles de pesca y acuicultura por países, Costa Rica. FAO, Rome

Faria VV, McDavitt MT, Charvet P, Wiley TR, Simpfendorfer CA, Naylor GJP (2013) Species delineation and global population structure of Critically Endangered sawfishes (Pristidae). Zool J Linn Soc 167:136-164

Fernandez-Carvalho J, Imhoff JL, Faria VV, Carlson JK, Burgess GH (2014) Status and the potential for extinction of the largetooth sawfish Pristis pristis in the Atlantic Ocean. Aquat Conserv 24:478-497

Gómez-Rodríguez S, Caldas JP, Acero AP, Martínez-Silva MA, Sáenz-Okuyama P, Lasso CA, Lasso-Alcalá OM (2014) Geographic distribution and conservation status of sawfish Pristis spp (Pristiformes: Pristidae) in the southern Caribbean Sea. Biota Colombiana Suplemento 1:109-117

Harrison LR, Dulvy NK (eds) (2014) Sawfish: a global strategy for conservation. IUCN Species Survival Commission's Shark Specialist Group, Vancouver

Hilje L, Fournier ML (2017) Un colono suizo en la ribera de Sarapiquí. Rev Herencia 30:198-260

*Hossain MA, Thompson BS, Chowdhury GW, Mohsanin S, Fahad ZH, Koldewey HJ, Islam MA (2015) Sawfish exploitation and status in Bangladesh. Aquat Conserv 25:781-799

Instituto Costarricense de Pesca y Acuicultura (INCOPESCA) (2017) Acuerdo de Junta Directiva número 3662017 (AJDIP/366-2017). Gobierno de la República de Costa Rica, Puntarenas

KKyne PM, Carlson J, Smith K (2013) Pristis pristis. The IUCN Red List of Threatened Species 2013: e.T18584848A 141788242. http://dx.doi.org/10.2305/IUCN.UK.2013-1. RLTS.T18584848A141788242.en (accessed 21 Sep 2017)

Leeney RH (2017) Are sawfishes still present in Mozambique? A baseline ecological study. PeerJ 5:e2950

Leeney RH, Downing N (2016) Sawfishes in The Gambia and Senegal-shifting baselines over 40 years. Aquat Conserv 26:265-278

KLeeney RH, Mana RR, Dulvy NK (2018) Fishers' ecological knowledge of sawfishes in the Sepik and Ramu rivers, northern Papua New Guinea. Endang Species Res 36: $15-26$

Lizano OG, Vargas JA (1993) Distribución espacio-temporal de salinidad y la temperatura en la parte interna del Golfo de Nicoya. Tecnol Marcha 12:3-16

Mainardi V (1996) El manglar de Terraba-Sierpe en Costa Rica. Centro Agronómico Tropical de Investigación y Enseñanza (CATIE), Proyecto Conservación para el Desarrollo Sostenible en América Central. Turrialba

McDavitt MT (2002) Lake Nicaragua revisited: conversations with a former sawfish fisherman. Shark News Newsl, IUCN Shark Specialist Group 14, Newbury

McDavitt MT (2014) Sawfish products and trade. In: Harrison LH, Dulvy NK (eds) Sawfish: a global strategy for conservation. IUCN Species Survival Commission's Shark Specialist Group, Vancouver, p 72-75

* Mendoza A, Kelez S, Gonzales Cherres W, Maguiño R (2017) The largetooth sawfish, Pristis pristis (Linnaeus, 1758), is not extirpated from Peru: new records from Tumbes. Check List 13:261-265

Ministerio del Ambiente los Recursos Naturales (MARENA) (2002) Resolución ministerial $N^{\circ} 54-02$ Vedas Nacionales de Especies Silvestres en Nicaragua. Gobierno de la República de Nicaragua, Managua

Ministerio del Ambiente y la Energía (2013) Resumen Ejecutivo del Plan de Manejo del Humedal Nacional Térraba-Sierpe. Gobierno de la República de Costa Rica, San José

Ogden LE (2015) Half shark, half chainsaw. New Sci 226: 40-45

Peverell SC (2009) Sawfish (Pristidae) of the Gulf of Carpentaria, Queensland, Australia. MS thesis, James Cook University 
Polidoro BA, Carpenter KE, Collins L, Duke NC and others (2010) The loss of species: mangrove extinction risk and geographic areas of global concern. PLOS ONE 5: e10095

Poulakis GR, Seitz JC (2004) Recent occurrence of the smalltooth sawfish, Pristis pectinata (Elasmobranchiomorphi: Pristidae), in Florida Bay and the Florida Keys, with comments on sawfish ecology. Fla Sci 67:27-35

Silva Benavides AM, Picado Barboza J, Mora Rodríguez F, Gonzalez Gairaud C (2015) Implicaciones sedimentológicas sobre el cambio en la cobertura del bosque de manglar en Boca Zacate, Humedal Nacional TérrabaSierpe, Costa Rica. Rev Biol Trop 63:591-601

Simpfendorfer CA (2000) Predicting population recovery rates for endangered western Atlantic sawfishes using demographic analysis. Environ Biol Fishes 58:371-377

Simpfendorfer CA, Kyne PM, Noble TH, Goldsbury J and others (2016) Environmental DNA detects Critically Endangered largetooth sawfish in the wild. Endang Species Res 30:109-116

Tabash Blanco FA (2007) Explotación de la pesquería de arrastre de camarón durante el período 1991-1999 en el Golfo de Nicoya, Costa Rica. Rev Biol Trop 55: $207-218$

Thorson TB (1976) Observations on the reproduction of the sawfish, Pristis perotteti, in Lake Nicaragua, with recommendations for its conservation. In: Thorson TB (ed)

Editorial responsibility: Austin Gallagher, Herndon, Virginia, USA
Investigations of the ichthyofauna of Nicaraguan lakes. University of Nebraska, Lincoln, NB, p 641-650

* Thorson TB (1982a) Life history implications of a tagging study of the largetooth sawfish, Pristis perotteti, in the Lake Nicaragua-Río San Juan system. Environ Biol Fishes 7:207-228

* Thorson TB (1982b) The impact of commercial exploitation on sawfish and shark populations in Lake Nicaragua. Fisheries (Bethesda, MD) 7:2-10

* Vargas JA (1995) The Gulf of Nicoya Estuary, Costa Rica: past, present, and future cooperative research. Helgol Meeresunters 49:821-828

*Wenger SJ, Isaak DJ, Luce CH, Neville HM and others (2011) Flow regime, temperature, and biotic interactions drive differential declines of trout species under climate change. Proc Natl Acad Sci USA 108:14175-14180

* White WT, Appleyard SA, Kyne PM, Mana RR (2017) Sawfishes in Papua New Guinea: a preliminary investigation into their status and level of exploitation. Endang Species Res 32:277-291

Winemiller KO (1983) An introduction to the freshwater fish communities of Corcovado National Park, Costa Rica. Brenesia 21:47-66

Zanella I, López A, Arauz R (2009) Caracterización de la pesca del tiburón martillo, Sphyrna lewini, en la parte externa del Golfo de Nicoya, Costa Rica. Rev Ciencias Mar Costeras 1:175-195

Submitted: November 16, 2018; Accepted: September 17, 2019 Proofs received from author(s): November 21, 2019 